\title{
STUDI KOMPARATIF FATWA YUSUF QARDAWI DAN SYAIKH UTSAIMIN TENTANG HUKUM BERCADAR (MENUTUP WAJAH)
}

\author{
Silmi Affan Harahap \\ Pascasarjana UIN Sunan Gunung Djati Bandung \\ Jalan Soekarno-Hatta, Kel. Cimincrang, Kec. Gedebage, Bandung \\ Email: silmiharahap29@gmail.com
}

\begin{abstract}
Abstrak
Al-Hijab merupakan pakaian yang digunakan untuk menutupi seluruh tubuh perempuan yang haram untuk diperlihatkan. Bercadar merupakan konsekuensi logis dari proses pembelajaran lebih intens mengenai hakikat perempuan. Cadar sering kali diasosiasikan dengan atribut organisasi Islam yang fanatic, fundamental, dan garis keras. Hal ini lebih kuat melekat manakala pemberitaan di media massa member label batu bagi perempuan yang bercadar dengan istri teroris. Dalam "Al Mu'ashiraah atau Fatwa Kontemporer" Yusuf Qardhawi menjawab sebuah pertanyaan tentang "Apakah memakai cadar itu bid'ah" yang menurutnya bahwa pada kenyataannya mengidentifikasi cadar sebagai bid'ah yang datang dari luar serta sama sekali bukan berasal dari agama dan bukan dari Islam, bahkan menyimpulkan bahwa cadar masuk ke kalangan umat Islam saat zaman kemunduran yang parah, tidaklah ilmiah dan tidak tepat sasaran. Identifikasi ini hanyalah perluasan yang merusak inti persoalan dan hanya menyesatkan usaha untuk mencari kejelasan yang sebenarnya. Syaikh Utsaimin berpendapat bahwa setiap wanita muslimah untuk menutup wajahnya dengan cadar itu serupa dengan pendapat yang beliau anggap sebagai muta'akhirin, yaitu pendapat Ibnu Ruslan dalam kitab Nailul Authar karena manu sia lemah keimanannya dan kebanyakan perempuan di antara mereka tidak menjaga kehormatan, maka yang wajib adalah menutup wajah.
\end{abstract}

\section{Kata kunci:}

Fatwa, Hijab, Cadar

\section{A. Pendahuluan}

Dalam fiqh Islam, al-Hijab adalah pakaian penutup yang digunakan untuk menutupi seluruh tubuh perempuan yang haram untuk diperlihatkan. Ada 3 kalimat yang memiliki makna yang sepadan dengan hijab, yaitu jilbab, khimar, dan niqab. ${ }^{1}$

${ }^{1}$ Abdul Qadir Mansur, Buku Pintar Fiqih Wanita, (Jakarta: Penerbit Zaman, 2012), hlm.254 
Padanan kata hijab dengan jilbab. Kalangan Fuqaha berbeda pendapat dalam menetukan bentuk jilbab (jilbab yang dimaksudkan penafsiran atas ayat yang termaktub dalam Qs. Al-Ahzab ayat 59). Satu pendapat mengatakan jilbab adalah baju kurung (mula'ah) yang menutup seluruh tubuh perempuan kecuali bagian mata. Pendapat lain menyatakan jilbab adalah semacam kerudung (rida') yang menutup bagian atas sampai bagian bawah tubuh perempuan, termasuk wajah. ${ }^{2}$

Khimar atau kerudung adalah kain yang digunakan untuk menutup kepala dan diulurkan sampai ke atas dada. Sebagaimana yang Allah jelaskan dalam Qs.An-Nur: 31. Dan tidak dibiarkan terurai rambutnya begitu saja sebagaimana yang dilakukan kaum jahiliyyah. ${ }^{3}$

Cadar atau niqab (نب) adalah kain yang digunakan untuk menutup wajah dan kepala. Kata hijab dan niqab dianggap padanan kata yang memiliki kemiripan. Perbedaanya kata hijab disebutkan dalam al-Qur'an sedangkan niqab tidak. Namun kalimat niqab digunakan dalam hadits yang ditadwin oleh Abu daud dalam Sunannya di hadits nomor. 2448. Makna dari hijab adalah menutup seluruh tubuh perempuan. Sedangkan niqab lebih dikhususkan untuk menutup wajah perempuan saja. ${ }^{4}$

Setelah diketahui perbedaan singkat dari definisi hijab, jilbab, niqab dan khimar, pembahasan yang menjadi fokus penulis dalam melakukan penlitian skripsi ini terletak pada hukum bagaimanakah wajah seorang wanita memakai cadar dalam berhijab.

Bercadar 5 adalah konsekuensi logis dari proses pembelajaran lebih intens mengenai hakikat perempuan. Permasalahannya cadar seringkali diasosiasikan dengan atribut organisasi Islam yang fanatik, fundamental dan garis keras. Hal ini lebih kuat melekat manakala pemberitaan di media massa memberi label baru bagi perempuan bercadar yakni istri teroris. ${ }^{6}$

\footnotetext{
2 Ibid., hlm.255

3 Yusuf Qardhawi, Fatawa al-Mu'ashirah, alih bahasa oleh: As'ad Yasin (Jakarta: Gema Insani, 2014), hlm.440

${ }^{4}$ Abdul Qadir Mansur, Buku Pintar Fiqih, hlm 257

${ }^{5}$ Menurut KBBI Cadar adalah kain yang digunakan untuk menutup wajah dan kepala, http://kbbi.web.id/cadar diakses pada tanggal 8 Juni 2016

${ }^{6}$ Lintang ratri,“Cadar, Media, dan Identitas Muslim” dalam ejournal.undip.ac.id/ index. php/forum/article/viewFile/3155/2832, tahun 2011. Diakses pada tanggal 28 Januari 2016
} 
Kalimat Ziinathunna dalam firman Allah Qs An-Nur [24] : ayat 31 dimaknai oleh Ibnu katsir sebagai perhiasan. ${ }^{7}$ Perhiasan adalah sesuatu yang digunakan untuk memperelok. Sebagian pakar menyebutkan bahwa sesuatu yang elok itu adalah yang menghasilkan kebebasan dan keserasian. ${ }^{8}$ Menurut Nashirudin Al-bani tidak diperkenankan bagi wanita untuk menampakkan perhiasannya dihadapan orang-orang ajnabi yang bukan mahramnya, kecuali bagian yang biasa nampak tanpa mereka sengaja. Dan ketidaksengajaan tadi tidak menjadi dosa bagi mereka bila dengan segera mereka tutup lagi. ${ }^{9}$

Allah berfirman dalam Qs Al-Ahzab (33) : 59

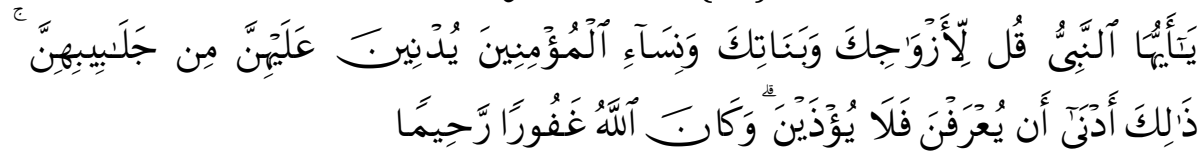

Ayat-Ayat diatas menjadi nash bagi ulama untuk menetapkan hukum dan adab dalam menggunakan cadar (bagi ulama yang mewajibkan) dan sekaligus bagi ulama yang menganggapnya sebagai ikhtilaf (diperbolehkannya seseorang tidak bercadar). ${ }^{10}$

Perihal ayat diatas Ibnu Katsir menafsirkan dari Ali Ibnu Thalhah telah meriwayatkan dari Ibnu Abbas, bahwa Allah memerintahkan kepada kaum wanita yang beriman apabila mereka keluar rumah untuk suatu keperluan, hendaklah mereka menutupi wajah mereka dimulai dari kepala mereka dengan kain jilbab dan hanya diperbolehkan menampakkan sebelah matanya saja. ${ }^{11}$

\section{B. Fatwa Yusuf Qardhawi tentang Hukum Bercadar}

Yusuf Qardhawi adalah seorang ulama kontemporer yang menulis banyak tentang berbagai macam pendapatnya tentang tafsir Al-Qur'an, Hadits, Aqidah, Syari'ah, fiqh dan tertuang dalam bentuk fatwa. Sehingga tidak heran banyak fatwanya yang telah dikodifikasi menjadi kitab

7 Ibnu Katsir, TafsirAl-Quranul 'Adzhim, alih bahasa oleh Bahrun Abu Bakar (Bandung: Sinar Baru Algensindo, 2007), Juz ke-22 hlm. 274

8 M.Walid, Etika Berpakaian Bagi Perempuan (Malang: UIN Maliki Press, 2011), hlm.21

${ }^{9}$ Muhammad Al-Bani N. Jilbab al-Mar'atul Muslimah fi Kitab wa As-Sunnah, alih bahasa Hidayati, cet ke-1, (Jogjakarta: Media Hidayah, 2002), hlm. 47-48

10 Yusuf Qardhawi, Fatawa al-Mu'ashirah. Alih bahasa oleh As'ad Yasin "Fatwa Kontemporer" (Jakarta: Gema Insasni, 2014) hlm. 453

${ }^{11}$ Ibnu Katsir, TafsirAl-Quranul 'Adzhim . Alih bahasa oleh Bahrun Abu Bakar (Bandung: Sinar Baru Algensindo, 2007) Juz ke-22 hlm. 193 
fatwa yang laris dan banyak dicari.12 Kitab Fatwa yang menjadi bahasan penulis adalah fatwa beliau dalam kitab Fatawa al-Mu'ashiraah yang diterjemahkan menjadi "Fatwa Kontemporer". Dalam Bab "Apakah memakai cadar itu bid'ah", dan "Apakah memakai cadar itu wajib”.

Pertanyaan yang diajukan Mahasiswi Al-Azhar adalah terkait kasus mashasiswi Al-Azhar Kairo, yang mengajukan suatu mosi keberatan berupa gugatan kepada pengadilan di Mesir karena adanya keputusan dari dekan mereka yang menyebabkan mereka mesti membuka cadar apabila mereka hendak memasuki area kampus. Putusannya adalah kesiapan mereka untuk membuka cadar manakala diperlukan dan apabila ada tuntutan dari pihak yang bertanggung jawab pada waktu ujian atau lainnya. ${ }^{13}$ Kejadian tersebut dibenarkan oleh Ustadz Ahmad Bahaudin dengan menulis artikel dalam surat kabar Al-Ahram tentang komentarnya terhadap putusan pengadilan.

Menurutnya cadar dan penutup wajah lainnya adalah sesuatu yang bersifat bid'ah yang masuk dalam kalangan Islam. Hal ini diperkuat pula oleh pendapat salah seorang Dosen Al-Azhar yang mengaku sebagai Dekan Fakultas Ushuluddin. Sehinggga mahasiswi Al-Azhar yang bertanya (mustafti) memohon kebijaksanaan dari jawaban Yusuf Qardhawi tentang masalah ini.14

Yusuf Qardhawi berpendapat: “Pada kenyataannya, mengidentifikasi cadar sebagai bid'ah yang datang dari luar serta sama sekali bukan berasal dari agama dan bukan dari Islam, bahkan menyimpulkan bahwa cadar masuk ke kalangan umat Islam saat zaman kemunduran yang parah, tidaklah ilmiah dan tidak tepat sasaran. Identifikasi seperti ini hanyalah bentuk perluasan yang merusak inti persoalan dan hanya menyesatkan usaha untuk mencari kejelasan yang sebenarnya". ${ }^{15}$ Mengenai pendapat seperti ini Yusuf Qardhawi berpendapat bahwa halhal ini adalah hal yang masuk kedalam kategori Ijtihadiyah Khilafiyyah. Sebab perbedaan pendapat kembali kepada pandangan mereka terhadap nash-nash yang berkenaan dengan masalah ini. Karena tidak didapatinya nash yang Qath'i Tsubut (jalan periwayatannya) dan dilalahnya (petunjuknya) mengenai masalah ini.

\footnotetext{
12 Yusuf Qardhawi, Fatawa al-Mu'ashirah. Alih bahasa oleh As'ad Yasin "Fatwa Kontemporer" (Jakarta: Gema Insasni, 2014) hlm. Pengantar Penerbit

${ }^{13}$ Ibid., hlm.424

14 Ibid., hlm.425

${ }^{15}$ Ibid.
} 
Mereka berbeda pendapat dalam menafsirkan Firman Allah dalam Qs An-Nur 31:

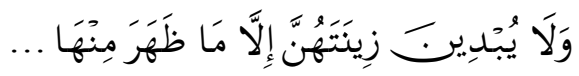

...dan janganlah mereka menampakkan perhiasannya, kecuali yang (biasa) nampak dari padanya... ${ }^{16}$

Mereka meriwayatkan dari Ibnu Abbas bahwa beliau menafsirkan "apa yang biasa tampak" itu dengan celak dan cincin. Penafsiran yang sama juga diriwayatkan dari Anas bin Malik dan Aisyah. Terkadang Ibnu Abbas menyamakan celak dan cincin, kepada pemerah kuku, gelang, anting-anting, kalung. ${ }^{17}$

Mereka meriwayatkan dari Ibnu Abbas yang merupakan kebalikan dari penafsiran yang pertama tadi. Mereka meriwayatkan dari sebagian tabi'in yakni Ubaidah As-Salmani bahwa beliau menafsirkan "mengulurkan jilbab" dengan penafsiran praktis (dalam bentuk peragaan), yaitu beliau menutup muka dan kepala dan membuka mata beliau yang disebelah kiri. Demikian pula yang diriwayatkan Muhammad Ka'ab al-Qurazhi.18

Dalam hal ini Yusuf Qardhawi termasuk kepada orang yang menguatkan pendapat yang mengatakan bahwa wajah dan kedua telapak tangan adalah bukan aurat dan tidak wajib bagi wanita muslimah menutupnya. Karena menurutnya dalil dari pendapat yang ber kata demikian lebih kuat. Walaupun demikian beliau tetap menyadari adanya perbedaan pendapat dikalangan ulama masa kini seperti dikalangan ulama Arab dengan tokoh utamanya Abdullah bin Baz yang kemudian di teruskan oleh murid-muridnya, dan negara teluk lainnya seperti Suriah dengan ulama yang sampai saat ini masih hidup yaitu Dr. Muhammad Sa'id Ramadhan al-Buthi yang tetap mewajibkan wanita muslimah untuk menutup wajahnya. ${ }^{19}$ Terhadap Ustadz Bahaudin yang mengecam dan memandang bahwa menggunakan cadar merupakan suatu bid'ah atas suatu pendapat ulama Al-Azhar yang mewajibkan menutup wajahnya adalah sesuatu yang dicela oleh Yusuf Qardhawi. ${ }^{20}$ Karena menurutnya lemahnya pandangan hakikat agama, sedikitnya pemahamannya

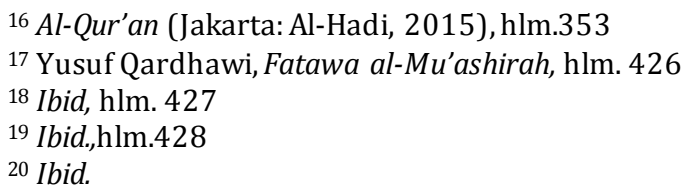


tentang fiqh serta kurang dalamnya penyelaman-penyelaman rahasiarahasia guna mengetahui tujuannya adalah sebab-sebab dari sikap ekstrimis. ${ }^{21}$ Jika memandangnya dengan hal-hal seperti demikian tergolonglah Ustadz Bahaudin kepadanya. Karena menurut Yusuf Qardhawi tidak ada satu ulama pun sejak dahulu hingga sekarang yang berpendapat bahwa haramnya mengenakan cadar secara umum kecuali saat ber-ihram. Dalam hal ini pun mereka hanya berpendapat, jaiz, mustahab dan wajib.22 Secara tegas beliau menyatakan bahwa:

"Bagaimana mungkin kita akan mengingkari wanita muslimah yang komitmen pada agamanya dan hendak memakai cadar! sementara mahasiswi-mahasiswi di perguruan tinggi al-Azhar itu ada yang mengenakan pakaian mini lagi tipis, membentuk potongan tubuhnya, dan memakai beracam-macam make-up, tanpa seorang pun yang mengingkarinya karena dianggapnya sebagai kebebasan pribadi. Padahal pakaian yang tipis yang menampakkan kulit atau tidak menutup bagian selain wajah dan kedua tangan itu di haramkan oleh syara'. Seandainya pihak yang bertanggung jawab dikampus melarang pakaian yang seperti itu mestilah didukung oleh Syara' dan undang-undang yang telah menetapkan bahwa agama resmi negara adalah Islam, dan bahwa hukum-hukum Islam merupakan sumber pokok perundangundangan." 23

Dalil yang telah dikemukakan di atas adalah kemashlahatan yang ditempuh oleh seorang mufti yang merupakan kemashlahtan hakiki yang diperoleh dari penunjukan suatu dalil hukum yakni mashlahah mursalah. Sebagaimana dikatakan Abdul Wahhab Khalaf bahwa apabila suatu kemashlahatan diperoleh dari pertimbangan yang sesuai syari'at. Kemashlahatan seperti itu belum ditetapkan hukumnya oleh Syara', juga belum ada dalil tentang dianggap atau tidaknya kemashlahatan itu. Maka kemashalahatan itu ditunjuk berdasarkan mashlahah mursalah. ${ }^{24}$

Pada bab selanjutnya. Mustafti yang berbeda datang dengan permasalahan berbeda, menuntut kejelasan hukum seperti apakah yang

21 Yusuf Qardhawi, Al-Shahwah Al-Islamiyah bain Al-Juhud Wa Al-Tatharruf, Alih bahasa oleh: Alwi (Bandung: Mizan, 1993), hlm. 53

22 Yusuf Qardhawi, Fatawa al-Mu'ashirah. Alih bahasa oleh As'ad Yasin "Fatwa Kontemporer" (Jakarta: Gema Insasni, 2014), hlm. 429

${ }^{23}$ Ibid., hlm.430

${ }^{24}$ Abdul Wahhab Khalaf, Ilmu Ushl Fiqh. Alih bahasa oleh: Faiz Muttaqin (Jakarta: Pustaka Amani, 2003), hlm.111 
dikeluarkan oleh Yusuf Qardhawi, setelah sebelumnya beliau bersikap moderat terhadap orang-orang yang membid'ahkan wanita yang menggunakan cadar. Namun, mereka yang memakai cadar menjelekjelekkan dan menganggap bahwa wajah yang dibuka merupakan sumber dari timbulnya fitnah meski mereka telah mengenakan jilbab. 25

Yusuf Qardhawi sendiri tidak menafikan akan semangat perbedaan yang terus menyala-menyala selama sebab-sebab perbedaan pendapat itu masih ada diantara manusia. Meskipun mereka sesama muslim, patuh pada agamanya dan ikhlas. Bahkan kadang-kadang komitmen dan keikhlasan terhadap agama menyebabkan perbedaan pendapat itu semakin tajam. Masing-masing pihak saling mengunggulkan dan memberlakukan pendapat diyakininya benar sebagai ajaran yang mendapat ganjaran bagi yang melaksanakan, dan mendapat hukuman bagi yang melanggar. ${ }^{26}$ Penyanggupan atas jawaban dikemukakan dengan mengatakan : "Dengan menyadari perbedaan pendapat itu akan senantiasa ada maka saya harus menjawab pertanyaaan ini dan saya akan mengulangi tema tersebut dengan menambahkan penjelasan".

Penjelasan dari Yusuf Qardhawi pun ditambah dengan menjadi lebih lengkap dan komprehensif. Dengan menghadirkan pendapat dan pandangan seluruh madzhab atas perkara yang mendukung pendapat beliau sebelumnya, yakni membolehkan membuka wajah dan tangan karena memang tiada syari'at yang mengharamkan dan melarang atas hal itu. Karena itulah pendapat para jumhur fuqaha dan para sahabat r.a.. Sehingga tidak semestinya dipertengkarkan pengamalannya. Sebagaimana yang dipertengkarkan sebagian yang ikhlas tetapi tidak berilmu dan oleh sebagian pelajar dan ilmuan yang bersikap ketat terhadap pendapat yang dikemukakan da'i kondang Syekh Muhammad Al-Ghazali dalam beberapa bukunya. ${ }^{27}$

\section{Landasan Dalil yang dipergunakan oleh Yusuf Qardhawi}

Dalil yang dikemukakan oleh Yusuf Qardhawi dalam menentukan putusan fatwanya sebagai pendapat beliau adalah sebagai berikut:

1. Firman Allah Qs An-Nur 3128:

25 Yusuf Qardhawi, Op.Cit., hlm 431

${ }^{26}$ Ibid.

${ }^{27}$ Ibid., hlm.473

${ }^{28}$ Nuhannad Shahib Thahar, Al-Qur'an Mushaf Al-Burhan, (Bandung: Fitrah Rabbani, 2009), hlm.353 


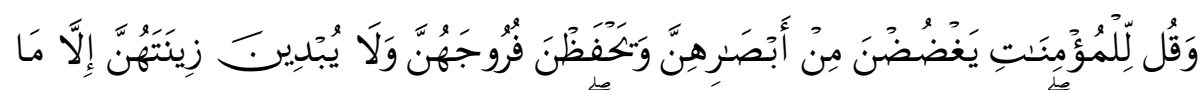

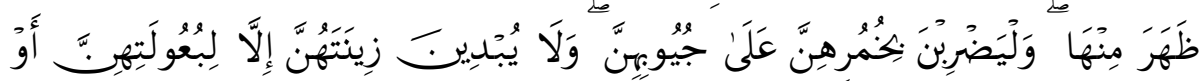

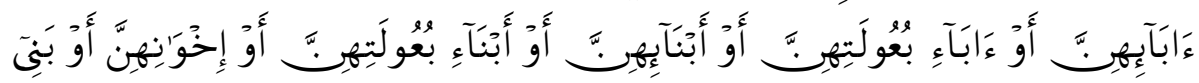

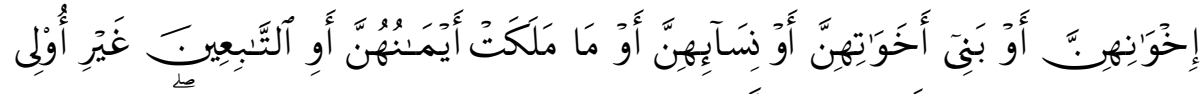

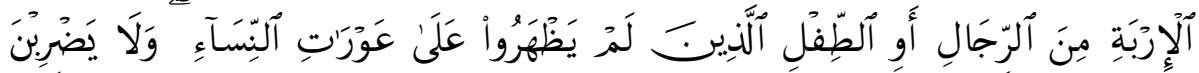

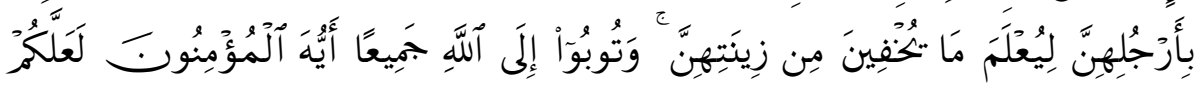
تُفْلِحُوبَ

Beliau membagi ke dalam dua kelompok pembahasan:



Pertama Ayat diatas diperkuat oleh penafsiran yang dikemukakan oleh sahabat Ibnu Abbas dari jalan yang jalan sanadnya tidak hanya satu dan seluruhnya sampai kepada-Nnya. Dengan penafsiran bahwa ayat yang biasa tampak itu adalah celak dan cincin. Lalu mengembangkan penafsiran tersebut dengan jalan Qiyash kepada pemerah kuku, gelang, anting-anting dan kalung. ${ }^{29}$

Yusuf Qardhawi memperkuat dalil diatas dengan hadits dari Aisyah: "Änak perempuan dari saudara laki-lakiku seibu, yaitu Abdullah bin thufail, pernah masuk ke tempatku dengan menggunakan perhiasan. Dia masuk ke tempat Nabi Saw., lalu kemudian beliau berpaling. Kemudian Aisyah berkata: sesunguhnya dia adalah anak perempuan dari saudara laki-lakiku dan dia seorang pembantu." Kemudian beliau bersabda: 30

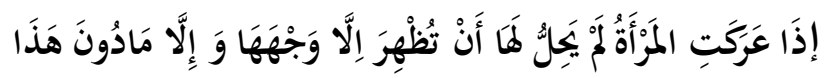

"Apabila ada seorang wanita telah dewasa, ia tidak boleh menampakkan selain wajahnya dan selain yang di bawah ini"

Seraya beliau memegang lengannya sendiri, lalu beliau biarkan antara pegangannya itu dengan telapak tangan sepanjang segenggam tangan sebagaimana termaktub dalam Ad-Durul Mantsur yang dikarang oleh As-Suyuthi dalam menafsirkan surat An-Nur.

${ }^{29}$ Yusuf Qardhawi, Fatawa al-Mu'ashirah. Alih bahasa oleh As'ad Yasin "Fatwa Kontemporer" (Jakarta: Gema Insasni, 2014), hlm. 426

${ }^{30}$ Ibid., hlm.439 
Kedua, Yusuf Qardhawi menerangkan untuk dalil selanjutnya adalah kutipan ayat:

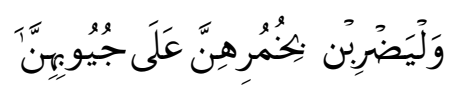

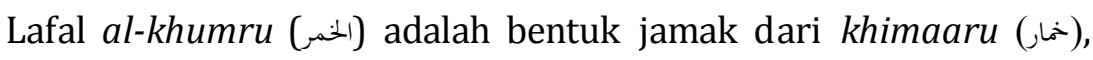
yaitu tutup kepala, sedangkan lafal al-juyuubu (الجيوب) adalah bentuk jamak dari kata jaybun (جَيْبَ), yaitu belahan dada pada baju atau lainnya. Maka wanita-wanita mukminah diperintahkan menutupkan dada dan mengulurkan penutup kepalanya sehingga dapat ditutupi leher dan dadanya, dan jangan membiarkannya terlihat sebagaimana yang dilakukan wanita-wanita jahiliah.

2. Kemudian ayat 30 dari Qs An-Nur yang berarti memerintahkan laki-laki untuk menahan pandangannya:

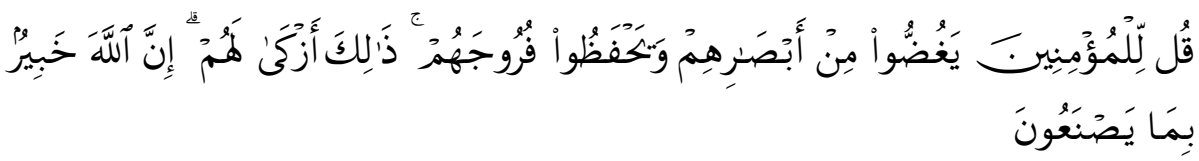

"Katakanlah kepada orang laki-laki yang beriman: "Hendaklah mereka menahan pandanganya, dan memelihara kemaluannya; yang demikian itu adalah lebih suci bagi mereka, sesungguhnya Allah Maha Mengetahui apa yang mereka perbuat". ${ }^{31}$

Ayat ini diperkuat dengan pernyataan Nabi dalam haditsnya yang mengatakan:

لا تتبع النظرة فإنما لك الأولى وليست لك الأخرة (رواه أحمد أبو داود والترمذى والحاكم عن

أبو هريرة)

"Janganlah engkau ikuti pandangan (pertama) dengan pandangan (berikutnya), karena engkau hanya diperbolehkan melakukan pandangan yang kedua" (HR. Ahmad,Abu Daud, Tirmidzi, Hakim dari Hurairah)

Maksudnya adalah jika seluruh wajah itu harus tertutup dan semua wanita harus memakai cadar, maka apakah arti anjuran untuk menahan pandangan? Dan apakah yang dapat dilihat oleh mata jika wajah itu tidak terbuka. Itu adalah makna yang dipahami oleh Yusuf Qardhawi.

${ }^{31}$ Muhammad Shahib Thahar, Al-Qur'an Mushaf Al-Burhan, (Bandung: Fitrah Rabbani, 2009), hlm.353 
3. Kemudian ayat 52 dari Qs Al-Ahzab:

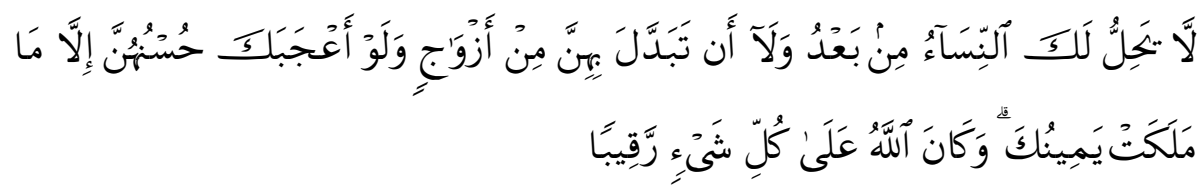

“Tidak halal bagimu mengawini perempuan-perempuan sesudah itu dan tidak boleh (pula) mengganti mereka dengan isteri-isteri (yang lain), meskipun kecantikannya menarik hatimu .."

Ayat di atas menandakan adanya indikasi diperkenankannya wajah untuk dilihat, pada frasa kata "meskipun kecanktikannya menarik hatimu." Frasa ini dimaknai oleh Yusuf Qardhawi dengan maksud bahwa kecantikan hanya dapat dipandang dengan cara wajah harus terbuka, sebagaimana kita ketahui bahwa pusat kecantikan wanita itu berasal dari wajah. ${ }^{32}$

4. Hadits: "Apabila salah seorang diantara kamu melihat wanita lantas ia tertarik kepadanya."

Nash-nash dan fakta-fakta menunjukkan bahwa umumnya kaum wanita pada zaman Nabi Saw. jarang sekali yang memakai cadar, bahkan wajah mereka bisa terbuka.

Imam Ahmad meriwayatkan kisah itu dari hadits Abi Kabsyah alAnmari bahwa Nabi Saw. bersabda:

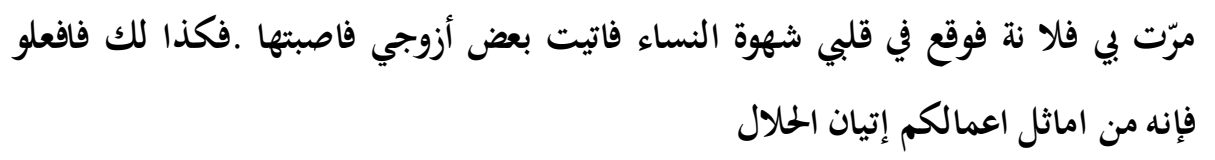

"Seorang Wanita (si Fulanah) melewati saya, maka timbullah hasrat hatiku terhadap wanita itu, lalu saya datangi salah seorang istri saya, kemudian campuri dia. Demikianlah hendaknya yang kamu lakukan, karena diantara tindakanmu yang ideal ialah melakukan sesuat yang halal." 33

Peristiwa yang menjadi sebab latar belakang timbulnya hadits ini menunjukkan bahwa Rasul yang mulia melihat seorang wanita tertentu, lantas timbul hasratnya terhadap wanita itu, sebagaimana layaknya manusia dan seorang laki-laki. Tentu saja, hal ini tidak mungkin terjadi tanpa melihat wajahnya, sehingga dapat dikenal si Fulanah.

32 Ibid., hlm.442

33 Ibid., hlm.444. Lihat Albani Silsilah Ahadits Ash-Shahihah, nomor 235 
5. Hadits al-Khats'amiyah dan al-Fadhl bin Abbas

Imam Nasa'i meriwayatkan dari Ibnu Abbas r.a bahwa seorang wanita dari Khats'am meminta fatwa kepada Rasulullah Saw. pada waktu haji wada' dan Fadhl bin Abbas pada waktu itu membonceng Rasulullah. "Kemudian Fadhl melirik wanita itu, dan ternyata dia seorang wanita yang cantik. Rasulullah lantas memalingkan wajah Fadhl ke arah lain."

Lantas Imam Tirmidzi meriwayatkan hadits ini dari Ali: "Dan Nabi Saw. memalingkan wajah al-Fadhl. Lalu al-Abbas bertanya, "wahai Rasulullah mengapa engkau putar leher anak pamanmu?" beliau menjawab, "Aku melihat seorang pemuda dan seorang pemudi, dan aku tidak merasa aman terhadap gangguan setan kepada mereka." Tirmidzi berkata hadits ini Hasan Shahih. ${ }^{34}$

Kedua hadits diatas merupakan dasar dari penetapan Yusuf Qardhawi dalam menganggap wajah pada zaman Rasulullah tidak merupakan suatu kewajiban untuk menutupnya.

6. Hadits-hadits lain

Hadits yang diriwayatkan oleh Muslim dan Abu Daud (dan lafal ini adalah lafal Abu Daud):

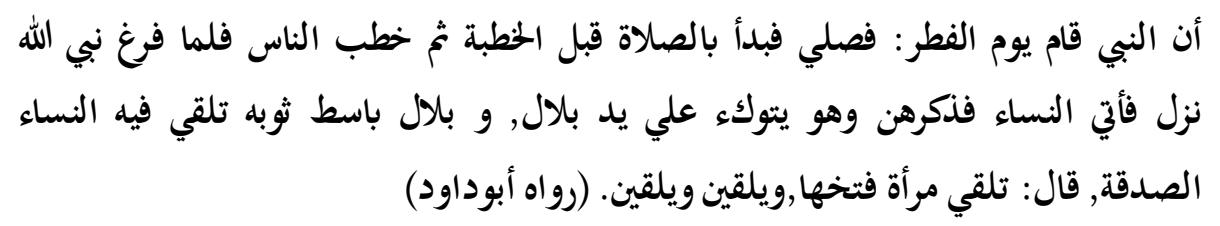

Penjelasan atas hadits diatas diperkuat dengan hadits yang diriwayatkan oleh Imam Bukhari dan Muslim dari Aisyah r.a., ia berkata: "Wanita-wanita mukminah menghadiri shalat bersama Nabi Saw. sambil menyelimutkan selimut mereka. Kemudian mereka pulang kerumah masing-masing setelah selesai menunaikan shalat, sedangkan mereka tidak dikenal (satu per satu) karena hari masih gelap." Mafhum dari riwayat ini menunjukkan bahwa wanita-wanita itu dapat dikenal jika hari tidak gelap, dan mereka itu hanya dapat dikenal jika wajah mereka terbuka. 35

Abu Daud meriwayatan dari Qais bin Syamas r.a., ia berkata: Seorang wanita yang bernama Ummu Khalad datang kepada nabi sambil

\footnotetext{
34 Ibid.

35 Ibid.
} 
mengenakan cadar (penutup muka) untuk menanyakan anaknya yang terbunuh. Lalu sebagian sahabat Nabi berkata kepadanya "Anda datang untuk menanyakan anak anda sambil mengenakan cadar?" lalu dia menjawab "Jika aku telah kehilangan anakku, maka aku tidak kehilangan perasaan maluku...”. Riwayat diatas menyatakan sikap sahabat yang menganggap aneh, menarik perhatian dan mengundang tanya, saat seorang wanita mengenakan cadar.

7. Tuntutan muamalah mengharuskan mengenal/mengetahui pribadi yang bersangkutan

Muamalah (pergaulan) seorang wanita dengan orang lain dalam berbagai persoalan hidup mengharuskan pribadinya dikenal dalam berbagai kegiatan muamalah. Baik ia sebagai penjual, pembeli, yang mewakilkan maupun yang menjadi wakil, menjadi saksi, menjadi penggugat ataupun tergugat. Karena itu para fuqaha telah bersepakat bahwa seorang wanita harus membuka wajahnya apabila sedang berperkara dimuka pengadilan, sehingga hakim mengetahui personalia saksi dan orang-orang yang berperkara. 36

Itu semua adalah dalil yang dikemukakan oleh Yusuf Qardhawi dari Al-Qurán hadits. Sebagaimana yang ia katakan bahwa, salah satu metodenya dalam menggali dalil adalah mengembalikan segala sesuatunya kepada Al-Qur'an dan Hadits, dan tidak fanatik terhadap salah satu madzhab. 37

\section{Syubhat Terakhir ${ }^{38}$}

Kalangan ulama yang mengatakan bahwa cadar itu wajib telah berkompromi dan menerima akan adanya suatu zaman, dimana zaman tersebut merupakan zaman dibolehkannya wanita untuk membuka wajahnya (walaupun yang menerima kebenaran akan masa ini, sebahagian golongan di antara mereka/sedikit).

Terhadap kasus tersebut mereka berpendapat kita harus mengerti bahwa zaman itu adalah zaman ideal di mana zaman tersebut akhlaknya bersih, rohaninya tinggi, wanita aman membuka wajahnya tanpa ada seorangpun yang mengganggunya yang berbeda dengan zaman sekarang yang penuh dengan kemudharatan serta kerusakan yang telah merajalela. Fitnah menyebar dimana-mana maka yang lebih utama dari-

\footnotetext{
36 Ibid., hlm.450

${ }^{37}$ Yusuf Qardhawi, Fatawa Mu'ashirah,al ih bahasa oleh Hamid al-Husaini (Jakrta: Pustaka Hidayah,2000) hlm.4

38 Ibid., hlm.459
} 
padanya adalah menutup wajah yang merupakan sumber dari segala fitnah itu berasal.

Maka jawaban atas tudingan itu adalah Pertama, bahwa meskipun awal periode ini adalah zaman ideal dimana zaman tersebut akhlaknya bersih, rohaninya tinggi, wanita aman membuka wajahnya tanpa ada seorangpun yang mengganggunya namun kita tidak lupa atas firman Allah dalam Qs. Al-Ahzab: 60-61

"Sesungguhnya jika tidak berhenti orang-orang munafik, orangorang yang berpenyakit dalam hatinya dan orang-orang yang menyebarkan kabar bohong di Madinah (dari menyakitimu), niscaya Kami perintahkan kamu (untuk memerangi) mereka, kemudian mereka tidak menjadi tetanggamu (di Madinah) melainkan dalam waktu yang sebentar dalam keadaan terlaknat. Di mana saja mereka dijumpai, mereka ditangkap dan dibunuh dengan sehebat-hebatnya" 39

Yang mengindikasikan bahwa seungguhnya ada orang yang masih suka berbuat zinah dan mengganggu kaum wanita, gila dan sinting dan mereka tidak mau meninggakan perbuatan mereka itu.

Kedua bahwa dalil syariah itu bila sudah sah dan jelas maka ia bersifat umum dan abadi. Ia bukan dalil untuk satu atau dua periode saja melainkan berlaku untuk selamanya. Sebab jika demikian syari'at itu hanya bersifat temporal dan non-abadi hal itu berentangan dengan predikat nya yaitu syari'at terakhir.

Ketiga yang benar adalah syari'at itu menghukumi bukan dihukumi, yang diikuti bukan yang mengikuti, dan kita wajib tunduk kepada syari'at bukan syari'at yang tunduk kepada hukum kita sebagaimana kita dapat menghalangi dan memunculkan kaidah wara'dan hatihati untuk menaskh syari'at. Itu sangat tidak dibenarkan.

9. Pendapat Jumhur Ulama ${ }^{40}$

Yusuf Qardhawi berpandangan bahwa jumhur ulama sepakat dengan kebolehan seorang wanita mengenakan cadar. alasannya:

a. Tidak ada penugasan dan pengharaman kecuali dengan Nash yang sharih dan shahih. Maksudnya adalah manusia pada dasarnya terbebas dari segala hukum yang taklif. Sampai ada

${ }^{39}$ Abdul Halim, Alqur'an Al-Hadi dan Terjemahnya, (Jakarta: Pustaka Al-Hadi, 2015), hlm.426

40 Yusuf Qardhawi, Op.Cit., hlm. 461 
nash yang pasti untuk mengaturnya. Sedangkan mengenai membuka wajah dan telapak tangan tidak ada nash yang secara shahih dan sharih mengharamkannya. Andai kata Allah mengharamkannya pastilah Allah akan secara tegas mengharamkannya, karena dia telah berfirman:

“...Sesungguhnya Allah telah menjelaskan kepadamu apa yang diharamkan-Nya atasmu, kecuali apa yang terpaksa kamu memakannya..." 41

b. Perubahan fatwa karena perubahan zaman. Ini adalah kaidah yang tidak ada pertentangan atasnya dan menjadi maklumat dikalangan jumhur ulama. Sungguh musuh-musuh Islam seperti misionaris, Marxis, orientalis, mereka menjelek-jelekkan dan mengekspos suatu kejadian dan menyandarkannya kepada Islam beserta ajaran syari'atnya. Padahal yang demikian itu tidak cocok sedikitpun dengan gambaran aslinya. Oleh karena itu keunggulan kita adalah dengan menempatkan dan membuktikan bahwa peran serta kaum perempuan dengan segenap kemampuannya, harus ditempatkan dalam hak-hak dan fitrahnya sesuai syari'atnya.

c. Akan timbul bencana umum. Yusuf Qardhawi menyadarkan dengan pernyataannya:

"Sesungguhnya peperangan ini bukan sebatas wajah dan telapak tangan yang diperbolehkan untuk menampakkannya atau tidak. Tetapi perangan sesungguhnya adalah kepada mereka yang hendak menjadikan wanita muslimah sebagai potret waita barat, dan hendak melepaskan dan melucuti ghirah Islamiyyahnya, lantas meeka keluar rumah dengan berpakain tapi telanjang serta berlenggak-lenggok. Karena itu janganlah para kaum yang "menyerukan cadar" membidikkan panahnya kepada saudara-saudara mereka yang berhijab, yang merasa mantap dengan jumhur umat. Tetapi hendaklah kepada mereka yang menyerukan budaya buka-bukaan dan melepaskan adab Islam"

d. Masyaqqah (kesulitan) mendatangkan kemudahan. Sesungguhnya kita dengan zaman seperti sekarang ini sungguh memberatkan, memberikan kesukaran dan kesulitan serta kemela-

${ }^{41}$ Abdul Halim, Alqur'an Al-Hadi dan Terjemahnya, (Jakarta: Pustaka Al-Hadi, 2015), hlm. 143 
ratan jika mewajibkan kepada wanita beriman untuk memakai cadar dan menutup telapak tangan mereka.

\section{Metode Istinbath Hukum Yusuf Qardhawi}

Metode Istinbath hukum yang ditawarkan oleh Yusuf Qardhawi sebagaimana yang ter dapat dalam pembukaan ${ }^{42}$ bahwa beliau termasuk salah satu pengusung konsep Ijtihad yang kontemporer.

Karena menurut beliau yang dimaksud dengan aliran yang moderat adalah aliran yang mengambil jalan tengah. Dan ini adalah sebaikbaik prinsip dalam memutus suatu perkara. ${ }^{43}$

Pada prinsipnya secara umum ijtihad yang dilakukan Yusuf Qardhawi terbagi kedalam dua macam cara:

a. Ijtihad Tarjih Intiqai ${ }^{44}$

Ijtihad ini adalah ijtihad yang bertujuan untuk menilik salah satu pendapat terkuat diantara beberapa pendapat yang ada dalam pusaka peninggalan fiqh kita, yang penuh dengan fatwa atau keputusan hukum. Alat pengukur tarjih Intiqa'i ini adalah: ${ }^{45}$

1) Hendaknya pendapat itu lebih cocok dengan orang zaman sekarang.

2) Hendaknya pendapat tersebut mencerminkan kepada rahmat kepada manusia.

3) Hendaknya pendapat itu lebih dekat kepada kemudahan yang diberikan oleh syara'.

4) Hendaknya pendapat itu lebih utama dalam merealisir maksud-maksud syara, mashlahat makhluk dan usaha untuk menghindari kerusakan manusia.

b. Ijtihad Insya'i

Maksudnya adalah mengambil konklusi hukum baru dalam suatu permasalahan, dimana permasalahan tersebut belum pernah dikemukakan oleh ulama yang terdahulu, baik masalah itu baru ataupun masalah yang telah lama.

\footnotetext{
${ }^{42}$ Yusuf Qardhawi, Fatawa al-Mu'ashirah. Alih bahasa oleh As'ad Yasin (Jakarta: Gema Insasni, 2014) hlm. Pengantar penerbit

43 Yusuf Qardhawi, Ijtihaad Fi AsySyari'ati al-Islamiyyah. Alih bahasa oleh Achmad Syathori (Jakarta: Bulan Bintang, 1987), hlm.259-260

44 Ibid., hlm.150-151

45 Ibid., hlm.169
} 
Artinya adalah apabila terjadi perselisihan pendapat antara pendapat yang kesatu dan kedua maka bolehlah seorang mujtahid untuk mengemukakan pendapat ketiga, dan begitu seterusnya.

Dalil yang dipaparkan oleh yusuf Qardhawi pada sub-bab sebelumnya menjelaskan bahwa apa yang dilakukannya dalam menetapkan dan menunjukkan dalil adalah mengacu kepada pendapat ulama yang rajih (kuat) atas penafsiran sahabat yang berpendapat bahwa hukum memakai cadar itu adalah ikhtilafiyyah. Dan ulama bersepakat untuk boleh membukanya. Lalu kemudian memperkuat pendapat jumhur ulama tersebut. Hal ini disebut juga sebagai Ijtihad Tarjih Intiqa'í. ${ }^{46}$

Yakni beliau memperkuat pendapat jumhur ulama yang telah bersepakat atas perbedaan pendapat. Dengan mengomparatifkan kedua belah pendapat, yang berbeda tersebut, dengan memberikan komentar terhadap pernyataan orang-orang yang bersikap ketat terhadap cadar ini." 47 Tujuan Yusuf Qardhawi membandingkannya adalah agar peristiwa tersebut menjadi jelas hukumnya sesuai dengan kesepakatan yang terjadi di mayoritas kalangan ummat muslim, dan para ulama.

\section{E. Fatwa Syaikh Utsaimin tentang Hukum Bercadar}

Syaikh Utsaimin menyebarluaskan pendapatnya mengenai kepastian hukum seorang muslimah dalam berjilbab, berkerudung dan menutup wajahnya dengan cadar, (sebagaimana di kawasan kerajaan Arab Saudi) dengan kitab fatwanya. Sehingga seluruh wanita muslim didunia menyadari betul hukum dari menutup wajah adalah wajib hukumnya, bukan sekedar tradisi Bangsa Arab saja. 48

Pendapat ini diterangkan lebih rinci dalam kitab Risalatul Hijab karya beliau yang memuat secara komprehensif alasan beliau mewajibkan mengenakan cadar. Menurut Syaikh Utsaimin, bahwa Firman Allah: 49
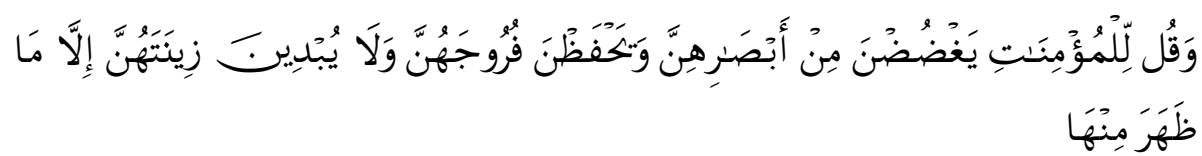

\footnotetext{
46 Ibid., hlm.150

47 Yusuf Qardhawi, Fatawa al-Mu'ashirah. Alih bahasa oleh As'ad Yasin (Jakarta: Gema Insasni, 2014) hlm.439

48 Muhammad Utsaimin, Risalatul Hijab, alih bahasa oleh: Abu Idris (Solo: Pustaka At-Tibyan, 2015), hlm.10-11

${ }^{49}$ Nuhannad Shahib Thahar, Al-Qur'an Mushaf Al-Burhan, (Bandung: Fitrah Rabbani, 2009), hlm.353
} 
Ayat diatas mengindikasikan bahwa sesungguhnya Allah memerintahkan wanita-wanita yang beriman untuk menjaga kemaluannya, dan perintah menjaga kemaluan berarti pula perintah melakukan halhal yang mengarah kepadanya. Hal-hal yang mengarah kepadanya inilah yang disebut sebagai menutup wajah oleh Syaikh Utsaimin.

Pemaknaan kalimat "zinatahunna" menurut Ibnu mas'ud sebagaimana dalam tafsir Ibnu Katsir menyatakan bahwa ayat itu bermakna kalimat perhiasan yang berbeda pada penyebutannya. Yang pertama perhiasan yang diindikasikan untuk orang yang boleh melihatnya (mahramnya) seperti wajah, celak, gelang dan cincin. Sedang yang kedua adalah perhiasan yang boleh dilihat oleh siapapun, perhiasan tersebut adalah kain yang digunakan untuk digunakan berupa pakaian. 50

Syaikh Utsaimin menegaskan, bahwa kewajiban setiap wanita muslimah untuk menutup wajahnya dengan cadar itu serupa dengan pendapat yang beliau anggap sebagai ulama muta'akhirin. yaitu pendapat Ibnu Ruslan dalam kitab Nailul Authar, yang berbunyi: "Karena manusia lemah keimanannya dan kebanyakan perempuan diantara mereka tidak menjaga kehormatan, maka yang wajib adalah menutup wajah".

\section{F. Metode Istinbath Hukum Syaikh Utsaimin}

Dari dalil-dalil Al-Qur'an dan Hadits serta pendapat para ulama yang beliau utarakan seluru hnya menggunakan metode secara washilah, serta keadaan yang menggambarkan baik digambarkan oleh nash maupun pendapat para sahabat.

Secara umum apa yang beliau lakukan terhadap penafsiran atas Qs. An-Nur ayat 31 adalah sadd Adz-dzari'ah. Sebagaimana kita ketahui dalam al-Muwafat, Asy-Syatibi bahwa sadd Adz-dzari'ah adalah menolak sesuatu yang boleh (jaiz) agar tidak mengantarkan kepada sesuatu yang dilarang (mamnu'). ${ }^{51}$

Kedudukan sadd Adz-dzari'ah dalam hak ini adalah sebagai cara atau metode untuk menemukan suatu dalil dari Syaikh Utsaimin, beliau mengatakan "Wanita yang memperlihatkan wajahnya adalah membuka jalan menuju pintu kejelakan. Dan apabila satu pintu kejelakan telah dibuka maka pintu-pintu yang lain pun akan mengikuti." 52

${ }^{50}$ Ibnu Katsir, Tafsir Al-Qurán Al- Adzhim, Juz ke-18, alih bahasa oleh: Bahrun Abu Bakar (Bandung: Sinar Baru Algesindo, 2007), hlm.275

51 brahim bin Musa al-Lakhmi al-Gharnathi al-Maliki (asy-Syathibi), alMuwafaqat fi Ushul al-Fiqh, (Beirut: Dara l-Ma'rifah,tt.), juz 3, hal. 257-258

52 Muhammad Shalih Utsaimin, Op.Cit., hlm.286 
Wajah adalah pusat kecantikan, apabila kecantikan tersebut dibiarkan terlihat dan diperhatikan oleh kaum pria, bukan tidak mungkin hal tersebut mengarah kepada perzinahan. Oleh karena itu menutup wajah merupakan sarana untuk menjaga kemaluan sebagaimana penafsiran beliau atas frase ayat ke 31 surat An-Nur "Dan Jagalah oleh kalian (wanita beriman) kemaluan kalian." ${ }^{53}$ Sebagaimana kaidah hukum cara sama dengan hukum tujuan. ${ }^{54}$

Pendekatan dengan metode Linguistik (kebahasaan), Maqaashid Syari'ah, dan Tarjih, menjadi suatu metode Thuruqul Istinbath Syaikh Utsaimin sebagaimna terlihat diatas. Artinya nash syara' secara eksplisit memberitahukan hal tersebut kepada mujtahid. Kemudian hukum kebalikan dari hukum yang telah ditetapkan dengan jelas oleh syari'at, dipahami secara luas dengan tujuan dari Maqashid Syariah yang dituju, lalu keudian beliau memperkuatnya dengan menunjukkan jalur periwayatannya yang shahih dan menguatkannya. 55

Pendekatan dengan ketiga cara itu sendiri terlihat pula pada penafsiran beliau atas ayat ke 60 surat An-Nur: "Dan perempuanperempuan tua yang telah terhenti (dari haid dan mengandung) yang tiada ingin kawin (lagi), tiadalah atas mereka dosa menanggalkan pakaian mereka dengan tidak (bermaksud) menampakkan perhiasan".

Beliau mengambil dalil dari kalimat ini dengan pemahaman bahwa 'illatnya adalah tergodanya kaum pria sehingga timbulnya fitnah, kemudian dengan pendekatan linguistiknya; sebagaimana yang diketahui bahwa menanggalkan pakaian disini bukan menanggalkan pakaian seluruhhnya melainkan penanggalan pakaian yang dilakukan seorang wanita ketika dirumah. Kemudian pendekatan dengan Maqashid AsySyari'ahnya adalah; wanita yang tidak tua dan dia masih menginginkan menikah utuk menutup wajahnya sebagaimana kutipan ayat "yang tidak bermaksud menampakkan perhiasannya". Lalu dengan penarjihan lewat berbagai hadits yang disampaikan diatas, sehingga tidak akan tergodanya kaum pria jika seorang wanita tua memperlihatkan wajahnya dan atau pergelangan tangannya. ${ }^{56}$

\footnotetext{
53 Muhammad Shalih Utsaimin, Risalatul Hijab, alih bahasa oleh: Abu Idris (Solo: Pustaka At-Tibyan, 2015), hlm.15-16

54 Ibid., Lih at : A.Djazuli, Ilmu Fiqh, (Jakarta: Kencana, 2010), hlm.98

55 Abdul Wahhab Khalaf, Ilmu Ushul Fiqh alih bahasa oleh : Faiz Muttaqin (Jakarta: Pustaka Amani, 2003), hlm. 219

56 Muhammad Shalih Utsaimin, Risalatul Hijab, alih bahasa oleh: Abu Idris (Solo: Pustaka At-Tibyan, 2015), hlm.21
} 
Dengan menggunakan pendekatan pendekatan tadi juga berlaku kepada hadits-hadits lain yang shahih menurut beliau. Syaikh Utsaimin lewat kaidah sadd Adz-dzari'ahnya berkesimpu-lan bahwa mana mungkin wajah sebagai sumber dari kecantikan dan sekaligus awal timbulnya fitnah dibiarkan terbuka, sedang kaki yang sudah tertutup harus ditutup karena mengundang nafsu? Ini tidak bisa diterima oleh akal sehat. Dan syari'at tidak mungkin menghendaki itu. Karena pengharaman yang dilakukan disini menurut syari'at adalah bukan lagi pada tahap 'pengharaman atas sarana' melainkan sudah sampai kepada 'pengharaman tujuan.'57

Interpretasi beliau terhadap hadits-hadits nabi serta pandangan para sahabat yang mana tokohnya adalah Ibnu Abbas dan seluruh jalur periwayatan yang melaluinya di maknai seperti demikian, adalah jawaban dari pertanyaan apakah memakai cadar itu wajib? Fatwa beliau mengatakan tidak, karena syari'at tidak memerintahkannya. Sedang segala sesuatu yang wajib perlu adanya alur perintah yang jelas secara Qath'i.

Yusuf Qardhawi berpandangan bahwa menggunakan cadar adalah termasuk kedalam masyaqqah (kesulitan), sedangkan dalam menerapkan hukum syari'at kesulitan itu harus mendatangkan kemudahan. Tetapi disisi lain beliau memuji dan membolehkan setiap orang yang bangga dengan pendapatnya dalam penggunaan cadarnya, selama mereka tidak menggolongkan kepada wanita yang berhijab namun tidak bercadar itu adalah fitnah dan tempat berkumpulnya dosa. Karena memang syari'at tidak melarang hal itu dan ini adalah Ijtihadiyah Khilafiyah.

Dalil-dalil keharusan itu berhijab menggunakan cadar merupakan dalil Naqli (merubah hukum asal, yakni diperbolehkannya membuka wajah), sedangkan dalil membuka wajah adalah Mutsbit (menegaskan hukum asal). Sebagaimana pendapat ahli ushul Dalil yang mengubah hukum asal lebih didahulukan, karena hukum tersebut bermakna konstansi berdasarkan apa yang telah ada.

\section{G. Studi Komparasi Pendapat Yusuf Qardhawi dan Syaikh Utsai - min mengenai Hukum Bercadar}

Silang pendapat yang terjadi diantara yusuf Qardhawi dan Syaikh Utsaimin terletak pada penafsiran dan interpretasi mereka terhadap

57 Muhammad Shalih Utsaimin, Fatawa Al-Muhimmah, alih bahasa oleh: Abdurrahman Abdullah Amin dkk, (Jakarta: Pustaka As-Sunnah, 2012), hlm.289 
suatu peristiwa hukum yang dimaknai dari Nash. Yang terjadi akibat tempat dan sosio kultural tempat mereka menetap.

Ayat Al-Qur'an yang jadi pokok mereka dalam menafsirkan sama yaitu Qs.An-Nur ayat 31. Tetapi mereka mengambil beberapa ayat lain sebagai penjelasnya sehingga penggunaan dalil dan interpretasi mereka itu berbeda.

Yusuf Qardhawi mengatakan bahwa ayat "Yang biasa tampak" tersebut mengandung makna perhiasan seperti wajah dan telapak tangan. Lalu kemudian beliau mengqiyashkannya kepada pemerah kuku, celak, gelang dan cincin, serta tempat dikenakannya perhiasan. ${ }^{58}$ Walaupun beliau tetap tidak menafikan akan adanya sebab-sebab perbedaan pendapat. Karena dari awal beliau sudah mewanti-wanti bahwa perihal hukum penggunaan cadar telah terjadi sejak periode sahabat sampai kepada kita sekarang. Dan hasilnya selalu berbeda pendapat.

Dalam hal ini interpretasi beliau terhadap hadits-hadits nabi serta pandangan para sahabat yang mana tokohnya adalah Ibnu Abbas dan seluruh jalur periwayatan yang melaluinya di maknai seperti demikian, adalah jawaban dari pertanyaan apakah memakai cadar itu wajib? Fatwa beliau mengatakan tidak, karena syari'at tidak memerintahkannya. Sedang segala sesuatu yang wajib perlu adanya alur perintah yang jelas secara Qath'i.

Yusuf Qardhawi berpandangan bahwa menggunakan cadar adalah termasuk kedalam masyaqqah (kesulitan), sedangkan dalam menerakan hukum syari'at kesulitan itu harus mendatangkan kemudahan. Tetapi disisi lain beliau memuji dan membolehkan setiap orang yang bangga dengan pendapatnya dalam penggunaan cadarnya, selama mereka tidak menggolongkan kepada wanita yang berhijab namun tidak bercadar itu adalah fitnah dan tempat berkumpulnya dosa. Karena memang syari'at tidak melarang hal itu dan ini adalah Ijtihadiyah Khilafiyah. ${ }^{59}$

Sedangkan Syaikh Utsaimin beranggapan bahwa kekeliruan pemahaman terjadi dikalangan da'i Sufur (da'i yang menyerukan kebolehan menampakkan wajah) adalah suatu pembukaan terhadap hal-hal yang mengandung fitnah didalamnya. Karena mereka telah membuka pintu keburukan. Dan membuka wajah adalah tujuan agar

\footnotetext{
58 Yusuf Qardhawi, Fatawa al-Mu'ashirah. Alih bahasa oleh As'ad Yasin "Fatwa Kontemporer" (Jakarta: Gema Insasni, 2014) hlm.433

${ }^{59}$ Ibid., hlm.428
} 
terlihatnya kecantikan seorang, yang dengannya dapat dilihat oleh seorang lelaki lalu kemudian terbayang oleh lelaki tersebut. Dan tidak diragukan lagi jalan menuju fitnah telah dibuka disaat pria tadi melihat kecantikannya. Oleh karena nya syari'at melarangnya lewat pemaknaan atas washilah. 60

Dan permasalahannya sudah jelas bahwa dinegara-negara yang membolehkan wanitanya untuk membuka wajah, apakah mereka puas hanya dengan memperlihatkan wajah saja? Tentu tidak jawabannya. Bahkan beberapa dari mereka ada yang menampakkan lehernya, pundaknya, bahkan sampai dadanya. Dan masayarakat sulit untuk mencegahnya. Ini semua merupakan akar dari dibukanya pintu-pintu kejelekan. Salah satunya adalah membiarkan wajah kaum wanita yang merupakan sumber fitnah tu dibiarkan terbuka. ${ }^{61}$

Karena sesungguhnya dalil-dalil keharusan itu berhijab dengan menggunakan cadar adalah dalil Naqli (merubah hukum asal, yakni diperbolehkannya membuka wajah), sedangkan dalil membuka wajah adalah Mutsbit (menegaskan hukum asal).sebagaimana pendapat ahli ushul Dalil yang merubah hukum asal lebih didahulukan, karena hukum tersebut bermakna konstansi berdasarkan apa yang telah ada. ${ }^{62}$

Yusuf Qardhawi mengemukakan pendapatnya bahwa yang paling penting dan dirasa perlu dalam mengemukakan perbedaan pendapat diantara kedua sisi disini adalah. 63

a. Membuka wajah disini tidak bermaksud untuk menghiasnya dan menambahkan warna-warna serta bedak dan parfum. Serta dengan sengaja memanjangkan kuku dan menghiasnya. Semua yang dibolehkan disini adalah perhiasan yang ringan, sebagaimana diriwaytkan Ibnu Abbas yakni celak dan cincin.

b. Pendapat yang tidak wajib bercadar tidak berarti tidak membolehkan untuk bercadar, silahkan saja untuk bercadar, jika itu merupakan pandangan dari orang yang bersikap hati-hati karena Yusuf Qardhawi belum menemukan dalil yang menunjukan

60 Muhammad Shalih Utsaimin, Fatawa Al-Muhimmah, alih bahasa oleh: Abdurrahman Abdullah Amin dkk, (Jakarta: Pustaka As-Sunnah, 2012), hlm.286

61 Ibid.

62 Muhammad Shalih Utsaimin, Risalatul Hijab, alih bahasa oleh: Abu Idris (Solo: Pustaka At-Tibyan, 2015), hlm.51

63 Yusuf Qardhawi, Fatawa al-Mu'ashirah. Alih bahasa oleh As'ad Yasin "Fatwa Kontemporer" (Jakarta: Gema Insasni, 2014) hlm.433 
kepada kewajiban bercadar karena ditakutkan ada fitnah pada wajah wanita.

c. Bahwa tidak ada kaitan antara membuka wajah dengan kebolehan melihat dan memandangnya. Dan yusuf Qardhawi pun tidak memungkiri sepakatnya beliau dengan pendapat apabila seorang wanita membuka wajahnya untuk membangkitkan syahwat padanya, atau dengan niat mengundang syahwat maka ia tidak segan-segan untuk setuju bahwa itu adalah haram.

Kedua pendapat yang saling kontra diatas sebenarnya sama sama memiliki tujuan yang sama yaitu apa maksud dan tujuan dari syari'ah itu sendiri (Maqashid Asy-Syari'ah). Sebagaimana yang sama-sama dikatakan oleh Yusuf Qadhawi dan Syaikh Utsaimin, poinnya adalah bahwa ada perbedaan pendapat dan ketidaktahuan serta ketidak pahaman yang terjadi dalam segi pengambilan dalil dan pemahaman atas suatu makna yang terkandung pada nash.

\section{H. Penutup}

Yusuf Qardhawi berpendapat mengenakan cadar hukumnya adalah mubah (boleh) karena Yusuf Qardhawi tidak menemukan satu dalil pun yang menunjukkan pengharaman didalamnya. Dan Syaikh Utsaimin berpendapat sebaliknya. Bahwa mengenakan cadar adalah wajib hukumnya, karena syari'at memerintahkan kita untuk menggunakannya. Dalil yang dikemukakan oleh Yusuf Qardhawi adalah Qs. An-Nur ayat 30 dan 31. Yang menandakan bahwa tidak ada indikasi kewajiban mengenakan cadar. Melainkan hanya berkhimar dan berjilbab. Karena sekiranya itu adalah hal yang wajib pastilah terang maka yang dimaksud syari'at.

Dalil yang dikemukakan oleh Syaikh Utsaimin adalah Qs An-Nur ayat 30 dan 60 serta Al-Ahzab ayat 59. Dan dari ayat tersebut Syaikh Utsaimin menemukan kewajiban memaki cadar yang tersirat secara jelas. Istibath hukum Yusuf Qardhawi adalah mashlahah mursalah karena tidak adanya nash yang mengatur dan membatasi dalm pemakaian cadar, sehingga dipandang baik dan diperbolehkan orang memakai cadar, atau tidak sama sekali juga tidak menimbulkan dosa. Ditambah dengan ijtihad intiqa'i yang memenangkan pendapat ulama yang membolehkan bercadar dengan penguatan dalil padanya. Sedangkan istinbath hukum Syaikh Utsaimin adalah saad Adz-Dzari'ah yang berarti hukum dari sarana adalah sama dengan tujuannya. Dan 
penggunaan cadar adalah sarana untuk menutup diri dari fitnah kaum pria. Persamaan pendapat mereka terletak pada tujuan mereka, yakni bersama-sama ingin memuliakan derajat wanita. Perbedaannya terletak pada cara bagaimana mereka memuliakan wanita.

\section{DAFTAR PUSTAKA}

Abdul Halim, 2015. Alqur'an Al-Hadi dan Terjemahnya, Pustaka Al-Hadi, Jakarta

Abdul Qadir Mansur, 2012. Buku Pintar Fiqih Wanita, Penerbit Zaman, Jakarta

Abdul Wahhab Khalaf, 2003. Ilmu Ushl Fiqh. Alih bahasa oleh: Faiz Muttaqin (Jakarta: Pustaka Amani,),

Ibnu Katsir, 2007. TafsirAl-Quranul 'Adzhim, alih bahasa oleh Bahrun Abu Bakar, Juz ke-22, Sinar Baru Algensindo,. Bandung

Ibrahim bin Musa al-Lakhmi al-Gharnathi al-Maliki (asy-Syathibi), alMuwafaqatfi Ushul al-Fiqh, (Beirut: Dara l-Ma'rifah, tt.),

M.Walid, 2011. Etika Berpakaian Bagi Perempuan. UIN Maliki Press. Malang

Muhammad Al-Bani N, 2002. Jilbab al-Mar'atul Muslimah fi Kitab wa AsSunnah, alih bahasa Hidayati, cet ke-1,: Media Hidayah, Jogjakarta

Muhammad Shahib Thahar, 2009. Al-Qur'an Mushaf Al-Burhan, Fitrah Rabbani, Bandung

Muhammad Shalih Utsaimin, 2012. Fatawa Al-Muhimmah, alih bahasa oleh: Abdurrahman Abdullah Amin dkk, Pustaka As-Sunnah. Jakarta

Muhammad Shalih Utsaimin, 2012. Fatawa Al-Muhimmah, alih bahasa oleh: Abdurrahman Abdullah Amin dkk, Pustaka As-Sunnah, Jakarta.

Muhammad Shalih Utsaimin, 2015. Risalatul Hijab, alih bahasa oleh: Abu Idris, Pustaka At-Tibyan. Solo,

Nuhannad Shahib Thahar, 2009. Al-Qur'an Mushaf Al-Burhan, Fitrah Rabbani. Bandung

Yusuf Qardhawi, 1993. Al-Shahwah Al-Islamiyah bain Al-Juhud Wa AlTatharruf, Alih bahasa oleh: Alwi, Mizan, Bandung:,

Yusuf Qardhawi, 2014. Fatawa al-Mu'ashirah, alih bahasa oleh: As'ad Yasin, Gema Insani, Jakarta 
42 | ‘Adliya Vol. 12, No. 1, Juni 2018

Yusuf Qardhawi, 2014. Fatawa al-Mu'ashirah. Alih bahasa oleh As'ad Yasin "Fatwa Kontemporer"Gema Insasni. Jakarta

Yusuf Qardhawi, Fatawa al-Mu'ashirah. Alih bahasa oleh As'ad Yasin "Fatwa Kontemporer" (Jakarta: Gema Insasni, 2014) 